\title{
Effect of Substitution of Nutritional Source through Organics and Bio Inputs on Corm and Cormel Production in Gladiolus (Gladiolus grandiflorus L.) cv. American Beauty
}

\author{
V. Priyadarshini ${ }^{1 *}$, A.V.D. Dorajee Rao ${ }^{2}$, T. Suseela ${ }^{3}$ and Swapnil Bharti ${ }^{4}$ \\ ${ }^{1}$ Horticultural College and Research Institute, Dr. Y.S.R. Horticultural University, \\ Venkataramannagudem, West Godavari dist. Andhra Pradesh, India \\ ${ }^{2}$ Department of Horticulture, Naini Agricultural Institute, Sam Higginbottom University of \\ Agriculture, Technology and Sciences, Allahabad, India
}

*Corresponding author

\begin{tabular}{|c|c|}
\hline & A B S T R A C T \\
\hline $\begin{array}{l}\text { Ke y w o r d s } \\
\text { Gladiolus, } \\
\text { Vermicompost, } \\
\text { Azotobacter, PSB, } \\
\text { KMB, Corms, } \\
\text { Cormels }\end{array}$ & \multirow{3}{*}{$\begin{array}{l}\text { The present work entitled as Effect of substitution of nutritional source through } \\
\text { organics and bio-inputs on corm and cormel production in gladiolus (Gladiolus } \\
\text { grandiflorus L.) cv. American Beauty was carried out at the college farm, } \\
\text { Horticultural College and Research Institute, Venkataramannagudem. The corm } \\
\text { and cormel characters were significantly influenced by different nutritional } \\
\text { sources. Application of } 75 \% \text { RDF }+25 \% \text { RDN through vermicompost }+ \\
\text { Azotobacter +PSB + KMB exhibited significant superiority in respect of corm } \\
\text { characters such as number of corms per mother corm, corm diameter, corm } \\
\text { weight, number of cormels produced per mother corm, cormel weight per plant } \\
\text { and corm number per hectare. }\end{array}$} \\
\hline Article Info & \\
\hline $\begin{array}{l}\text { Accepted: } \\
\text { 12 November } 2018 \\
\text { Available Online: } \\
10 \text { December } 2018\end{array}$ & \\
\hline
\end{tabular}

\section{Introduction}

Gladiolus, a native of South Africa is one of the most popular ornamental bulbous plant grown commercially for its fascinating flowers in many parts of the world and is popularly called as "Queen of bulbous" flowers. The term gladiolus was coined by Pliny the Elder (A.D-23-79) deriving from the Latin word "Gladius", because of its swordlike leaves. It is popularly known as sword lily. The modern hybrids are botanically known as Gladiolus grandiflorus belonging to family Iridaceae bearing chromosome number 60. In Europe it is also known as 'corn flag' because Gladiolus illyricus is found wild as weed in the corn fields. In the international cut-flower trade gladiolus occupies fourth place (Bhattacharjee and De, 2010). It is mainly cultivated for cut-flowers because of its elegant appearance and prolonged vase life. Gladiolus spikes are most popular in flower arrangements and for preparing attractive bouquets (Mishra et al., 2006). The 
magnificent inflorescence with various colour have made it attractive for use in herbaceous borders, beddings, rockeries, pots and for cutflowers.

The flowers open from bottom to upwards. The flowers may be frilly, ruffled or plain, solid coloured or multi-coloured and they come in every shade and colour combination imaginable. The upright growth habit of gladiolus lends itself to any manner of floral arrangements, from minimalist Japanese 'Ikebana' and 'Boroque' bouquets.

The crop benefiting microbial inoculants generally called as "biofertilizers" help in augmenting the crop productivity through effective mobilization of nutrients to the crop. These beneficial microorganisms are also known to secrete plant growth promoting substances like Indole Acetic Acid, Gibberellic Acid, Cytokinins, vitamins which are known to influence on the crop growth. Consequently, the role of bio-inoculants has been identified in improving the qualitative and quantitative characters of various crops. To ensure maximization of productivity in any crop, optimum nutrient supply is one of the important factors.

Different agro-techniques play an important role in growth and development of gladiolus crop, among them nutrition is one of the most important aspects which directly influences the spike yield and quality. Gladiolus being highly responsive crop to nutrition, it requires larger doses of macro nutrients viz., nitrogen, phosphorus and potassium (Dubey and Mishra, 2005). Crop yields in general are boosted by the application of chemical fertilizers since they play a significant role in supplying essential nutrient elements for intensive crop production which heralded green revolution in the country. Increased and indiscriminate use of chemical fertilizers in an unbalanced manner has created the problem of multiple nutrient deficiencies, diminishing soil fertility, deteriorating its structure and health making the yields unsustainable.

\section{Materials and Methods}

The investigation was carried out at the College Farm, Horticultural College and Research Institute, Venkataramannagudem, West Godavari district during Rabi 2016-2017 with an objective of finding out the effect of organic nutritional sources with reduced inorganic fertilizer dose on corm and cormel characters. The experiment was laid out in Randomised Block Design with nine treatments and replicated thrice. There were nine treatments consisting of $\mathrm{T}_{1}: 75 \% \mathrm{RDF}+$ $25 \%$ RDN through vermicompost (VC), $\mathrm{T}_{2}$ : $75 \% \mathrm{RDF}+25 \% \mathrm{RDN}$ through $\mathrm{VC}+$ Azotobacter, $\mathrm{T}_{3}: 75 \% \mathrm{RDF}+25 \% \mathrm{RDN}$ through $\mathrm{VC}+\mathrm{PSB}, \mathrm{T}_{4}: 75 \% \mathrm{RDF}+25 \%$ $\mathrm{RDN}$ through $\mathrm{VC}+\mathrm{KMB}, \mathrm{T}_{5}: 75 \% \mathrm{RDF}+$ $25 \%$ RDN through $\mathrm{VC}+$ Azotobacter $+\mathrm{PSB}$, $\mathrm{T}_{6}: 75 \% \mathrm{RDF}+25 \% \mathrm{RDN}$ through $\mathrm{VC}+$ Azotobacter $+\mathrm{KMB}, \mathrm{T}_{7}: 75 \% \mathrm{RDF}+25 \%$ $\mathrm{RDN}$ through $\mathrm{VC}+\mathrm{PSB}+\mathrm{KMB}, \mathrm{T}_{8}: 75 \%$ $\mathrm{RDF}+25 \% \mathrm{RDN}$ through $\mathrm{VC}+$ Azotobacter $+\mathrm{PSB}+\mathrm{KMB}, \mathrm{T}_{9}: 100 \% \mathrm{RDF}$ (30N: 20P: $9 \mathrm{~K}$ $\mathrm{g} \mathrm{m}^{-2}$ ). These corms were planted at $20 \mathrm{~cm}$ apart within a row spaced at $30 \mathrm{~cm}$ distance from the adjacent row at a depth of 5-6 cm in month of October. The recommended dosage of N, P, and K 300:200:90 kg/ha (Rajesh, L., 2016) was applied through Urea, Single Super Phosphate and Murate of Potash respectively. Calculated amount of vermicompost (325 g) was applied as per treatment to the plots one week before planting. Half the dose of nitrogen and complete dose of phosphorus and potash were supplied at the time of planting whereas the remaining half of nitrogen was applied 45 days after planting. The bio fertilizers viz., Azotobacter, PSB and KMB were added each at the rate $4 \mathrm{~kg} \mathrm{ha}^{-1}$ to the respective treatment plots (Pansuriya and Chauhan, 2015). 


\section{Results and Discussion}

\section{Number of corms produced per mother corm}

Significant differences were observed among the different nutritional treatments in the present study. The maximum number of corms produced per mother corm (3.88) by the application of $75 \% \mathrm{RDF}+25 \% \mathrm{RDN}$ through vermicompost + Azotobacter $+\mathrm{PSB}+\mathrm{KMB}$ $\left(\mathrm{T}_{8}\right)$ and minimum number of corms produced per mother corm (1.80) was recorded by application of $100 \%$ RDF (30N: $20 \mathrm{P}: 9 \mathrm{~K} \mathrm{~g} \mathrm{~m}^{-}$ $\left.{ }^{2}\right)\left(\mathrm{T}_{9}\right)$. The increase in number of corms per mother corm might be due to the better soil environment with the application of organics such as vermicompost, biofertilizers. This application of organics might have resulted in higher uptake of the nutrients into the plants. This higher uptake of nutrients resulted in good vegetative growth and further laid a path for the efficient transfer of more food substances into the corms at the end of the crop growth period. The results obtained by earlier workers Gangadharan and Gopinath, (2000) are found to be in conformity with those obtained in the present investigation (Table 1).

\section{Corm diameter $(\mathrm{cm})$}

There were significant differences with respect to corm diameter among the various treatment combinations. The maximum corm diameter $(5.65 \mathrm{~cm})$ was found by the application of $\mathrm{T} 8: 75 \% \mathrm{RDF}+25 \% \mathrm{RDN}$ through vermicompost + Azotobacter $+\mathrm{PSB}+$ $\mathrm{KMB}$ and minimum corm diameter $(3.70 \mathrm{~cm})$ was recorded by application of $\mathrm{T} 9: 100 \% \mathrm{RDF}$ (30N: 20P: $9 \mathrm{~K} \mathrm{~g} \mathrm{~m}^{-2}$ ). The increase in the diameter of the corm could be due to the better soil environment with the application of organics such as vermicompost, biofertilizers. This application of organics might have resulted in higher uptake of the nutrients into the plants. This higher uptake of nutrients resulted in good vegetative growth and sufficient amount of photosynthates could have accumulated which were transferred into the corms at the end of the crop growth period. The results of Gangadharan and Gopinath (2000) revealed similar facts.

\section{Corm weight (g)}

The corm weight per plant was found maximum $(48.29 \mathrm{~g})$ by application of $\mathrm{T} 8: 75 \%$ $\mathrm{RDF}+25 \%$ RDN through vermicompost + Azotobacter $+\mathrm{PSB}+\mathrm{KMB}$ and minimum corm weight (30.05 g) was observed by application of T9: $100 \%$ RDF (30N: 20P: 9K $\mathrm{g} \mathrm{m}^{-2}$ ). Increased weight of the corms might be due to better uptake of nutrients better vegetative growth and consequently accumulation of more photosynthetic assimilates during the active crop growth period. The result was in accordance with Godse et al., (2006) and Bhalla et al., (2006) in gladiolus.

\section{Number of cormels produced per mother corm}

There were significant differences with respect to the number of cormels produced per mother corm among the various treatments. The maximum number of cormels produced per mother corm (28.70) was found by application of $\mathrm{T} 8: 75 \% \mathrm{RDF}+25 \% \mathrm{RDN}$ through vermicompost + Azotobacter $+\mathrm{PSB}+$ $\mathrm{KMB}$ and minimum number of cormels produced per mother corm (21.63) was observed by application of T9: $100 \%$ RDF (30N: 20P: $9 \mathrm{~K} \mathrm{~g} \mathrm{~m}^{-2}$ ). In gladiolus the number of cormels per plant seems to be influenced by different substitutions of inorganics with organics and bio-fertilisers. Better nutrient uptake, more growth attributes and dry matter accumulation in the above treatments might have resulted in more cormel production. The result was in accordance with Godse et al., 2006 and Bhalla et al., 2006 in gladiolus. 
Table.1 Effect of substitution of nutritional source through organics and bio inputs on corm and cormel production in gladiolus (Gladiolus grandiflorus L.) cv. American Beauty

\begin{tabular}{|c|c|c|c|c|c|c|}
\hline Treatments & $\begin{array}{c}\text { No of corms/ } \\
\text { mother corm }\end{array}$ & $\begin{array}{c}\text { Corm } \\
\text { diameter } \\
(\mathrm{cm})\end{array}$ & $\begin{array}{c}\text { Corm } \\
\text { weight } \\
(\mathrm{g})\end{array}$ & $\begin{array}{c}\text { No of } \\
\text { cormels/mother } \\
\text { corm }\end{array}$ & $\begin{array}{c}\text { Cormel } \\
\text { weight per } \\
\text { plant }(\mathrm{g})\end{array}$ & $\begin{array}{c}\text { Corm } \\
\text { number } \\
\text { ha }^{-1}(000)\end{array}$ \\
\hline $\mathrm{T}_{1}$ & 2.18 & 4.06 & 33.15 & 23.33 & 26.76 & 218.66 \\
\hline $\mathrm{T}_{2}$ & 3.10 & 4.90 & 41.62 & 26.66 & 28.03 & 310.00 \\
\hline $\mathrm{T}_{3}$ & 2.48 & 4.27 & 37.09 & 25.30 & 26.33 & 248.66 \\
\hline $\mathrm{T}_{4}$ & 2.33 & 4.23 & 37.01 & 23.70 & 26.16 & 233.33 \\
\hline $\mathrm{T}_{5}$ & 3.30 & 5.14 & 44.23 & 27.63 & 28.03 & 330.00 \\
\hline $\mathrm{T}_{6}$ & 3.22 & 5.05 & 42.37 & 26.66 & 27.86 & 322.00 \\
\hline $\mathrm{T}_{7}$ & 2.53 & 4.35 & 37.47 & 26.10 & 27.90 & 253.33 \\
\hline $\mathrm{T}_{8}$ & 3.88 & 5.65 & 48.29 & 28.70 & 29.26 & 388.66 \\
\hline $\mathrm{T}_{9}$ & 1.80 & 3.70 & 30.05 & 21.63 & 23.46 & 180.00 \\
\hline $\mathrm{S} \mathrm{Em} \pm$ & $\mathbf{0 . 1 4}$ & $\mathbf{0 . 1 2}$ & $\mathbf{1 . 1 2}$ & $\mathbf{0 . 5 8}$ & $\mathbf{0 . 8 2}$ & $\mathbf{1 4 . 1 7}$ \\
\hline $\mathrm{CD}$ at $5 \%$ & $\mathbf{0 . 4 2}$ & $\mathbf{0 . 3 8}$ & $\mathbf{3 . 4 1}$ & $\mathbf{1 . 7 5}$ & $\mathbf{2 . 4 8}$ & $\mathbf{4 2 . 8 6}$ \\
\hline
\end{tabular}

\section{Cormel weight per plant $(g)$}

The cormel weight per plant was found significantly different among different nutritional source substitutions with or without bio-fertilisers. The maximum cormel weight $(29.26 \mathrm{~g})$ was found by application of $75 \% \mathrm{RDF}+25 \% \mathrm{RDN}$ through vermicompost + Azotobacter $+\mathrm{PSB}+\mathrm{KMB}$ (T8) and minimum cormel weight per plant (23.46 g) was observed by application of (T9) $100 \%$ RDF (30N: 20P: $9 \mathrm{~K} \mathrm{~g} \mathrm{~m}^{-2}$ ). Increased weight of cormels might be due to better uptake of nutrients, enhanced growth parameters, accumulation of metabolites, leading to more proliferation of cormels with a higher individual weight. Dongardive et al., (2007) and Godse et al., (2006) revealed similar results in gladiolus.

\section{Corm number per ha (000)}

There were significant differences with respect to number of corms per ha among the various treatments. The maximum number of corms produced per ha (1.88 thousands) was found in $\mathrm{T} 8$ containing $75 \% \mathrm{RDF}+25 \%$
RDN through vermicompost + Azotobacter + $\mathrm{PSB}+\mathrm{KMB}$ and the minimum number of corms per ha (8.13 thousands) was recorded by T9 containing $100 \%$ RDF (30N: 20P: 9K g $\mathrm{m}^{-2}$ ). The increase in number of corms per mother corm, corm weight, corm diameter, number of corms ha- 1 might be due to the better soil environment with the application of organics such as vermicompost, biofertilizers. This application of organics might have resulted in higher uptake of the nutrients into the plants. This higher uptake of nutrients which resulted in good vegetative growth might have played a role in the transfer of more food substance into the corms at the end of the crop growth period. The results of Gangadharan and Gopinath (2000) revealed similar results.

\section{Acknowledgement}

We authors are greatly thankful to other professors and members, Horticultural College and Research Institute, Dr. Y.S.R. Horticultural University, for their guidance and support during the research trail and also thankful to Department of Agro- metrology 
for providing me with all the weather data throughout my research period and also to the Department of Soil Science for allowing me to perform my lab experiments.

\section{References}

Bhalla, R., Priyanka, K., Dhiman, S.R. and Jain, R. 2006. Effect of bio-fertilizers and bio-stimulants on growth and flowering in gladiolus. Journal of Ornamental Horiculture. 9(4): 248-52.

Bhattacharjee, S. K. and De, L. C. (2010). Gladiolus Advanced Commercial Floriculture. Rev. Edn. Aavishkar Publ. Jodhpur, India 1: 309-310

Dongardive, S.B., Golliwer, V.J. and Bhanle, S.A. 2007. Effect of organic manure and bio-fertilizers on growth and flowering in gladiolus cv. White Prosperity. Plant Archives.7(2): 657-58.

Dubey, R.K. and Misra, R.L. 2005. Response of chemical and biofertilizers on corm and cormel production in gladiolus. Progressive Horticulture. 37(2): 41218.

Gangadharan, G.D. and Gopinath, G. 2000. Effects of organic and inorganic fertilizerson yield of spikes, corms, cormels and returns of gladiolus cv. White Prosperity. Karnataka Journal of Agricultural Sciences. 13(4): 937-41.

Godse, S. B, Golliwar, V. J., Neha C., Bramhanker, K. S. and Kore, M. S. 2006. Effect of organic manures and bio-fertilizers with reduced doses of inorganic fertilizers on growth, yield and quality of gladiolus. Journal of Soils and Crops. 16(2): 445-49.

Mishra, R. L., Hussain, C. T. S. and Misra, S. 2006. Gladiolus. Advances in Ornamental Horticulture 3. Pointer Pulb. Joinpur, India. 68-106.

Pansuriya, P.B and Chauhan, R.V. 2015. Effect of Integrated Nutrient Management on Growth, Yield and Quality of Gladiolus (Gladiolus grandiflorus L.) cv. Psittacinus Hybrid. Journal of Horticulture 2: 129.

Rajesh, L. 2016. Effect of corm weight and NPK levels on growth and flowering of gladiolus (Gladiolus grandiflorus L.) cv. American Beauty. M.Sc. Thesis. Dr, Y.S.R Horticultural University, Venkataramannagudem.

\section{How to cite this article:}

Priyadarshini, V., A.V.D. Dorajee Rao, T. Suseela and Swapnil Bharti. 2018. Effect of Substitution of Nutritional Source through Organics and Bio Inputs on Corm and Cormel Production in Gladiolus (Gladiolus grandiflorus L.) cv. American Beauty. Int.J.Curr.Microbiol.App.Sci. 7(12): 1505-1509. doi: https://doi.org/10.20546/ijcmas.2018.712.177 